Sari Pediatri, Vol. 6, No. 1, Juni 2004: 10-15

\title{
Konstipasi dan Faktor Risikonya pada Sindrom Down
}

\author{
Ina Rosalina, Sjarif Hidayat
}

Konstipasi adalah keterlambatan atau kesulitan buang air besar yang terjadi 1 sampai 2 kali per minggu atau lebih dari 3 hari secara berturut-turut. Angka kejadian konstipasi pada anak bervariasi antara $2-20 \%$, pada umumnya merupakan suatu gejala dari penyakit. Kegagalan dalam proses defekasi merupakan penyebab utama dari konstipasi dan hipotoni merupakan salah satu keadaan yang mengakibatkan terjadinya konstipasi tersebut. Sindrom Down merupakan kelainan kromosom yang dapat mengakibatkan terjadinya hipotoni pada seluruh sistem muskuloskeletal termasuk pada saluran cerna. Penelitian ini bertujuan untuk mengetahui persentase sindrom Down yang menderita konstipasi dan hubungan dengan faktor risikonya. Diagnosis sindrom Down ditegakkan berdasarkan pemeriksaan genetik di rumah sakit Hasan Sadikin, dibagi dalam tipe aberasi penuh dan tipe mosaik. Pada subyek diberikan kuesioner terstruktur yang berisi pertanyaan yang berhubungan dengan konstipasi dan faktor risikonya, 50 kuesioner kembali ke peneliti. Subyek berusia 3 - 10 tahun ( 27 wanita dan 23 pria), konstipasi ditemukan pada $32 \%$. Aberasi penuh lebih banyak yang menderita konstipasi (35\%) dibanding dengan mosaik (25\%). Encopresis ditemukan pada 30\% pasien sedangkan soiling pada $26 \%$ pasien. Baik encopresis maupun soiling lebih banyak ditemukan pada tipe mosaik ( $58,5 \%$; $38 \%)$ dibanding aberasi penuh $(26,7 \% ; 25 \%)$. Nyeri perut dan nyeri saat buang air besar berhubungan dengan kejadian konstipasi (r:0,5, p:0,002 ; r:0,56, p:0,002). Aktifitas berlebihan dan soiling berhubungan dengan kejadian encopresis $(r: 0.49, \mathrm{p}: 0,001 ; \mathrm{r}: 0,44$, p:0,005). Gangguan saluran kemih dan pemakaian obat obatan berhubungan dengan kejadian soiling ( $\mathrm{r}: 0,38$, p: 0,02; r:0,32, p:0,04). Kesimpulan, hampir setengah dari sindrom Down mengalami konstipasi, encopresis dan soiling; sedangkan tidak jelas faktor risiko mempengaruhi terjadinya konstipasi pada anak sindrom Down.

Kata kunci: konstipasi, sindrom Down, faktor risiko

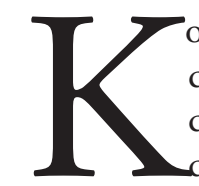
onstipasi adalah penyakit dengan kelainan defekasi. Konstipasi pada anak didefinisikan apabila seorang anak tidak seminggu hanya defekasi kung di 3 kali. Kead lain yang termasuk dalam konstipasi disebut soiling yaitu apabila buang air besar sedikit sedikit dan melekat

\footnotetext{
Alamat Korespondensi:

Ina Rosalina, dr., Sp.A

Bagian/SMF Ilmu Kesehatan Anak FKUP/RSUP dr. Hasan Sadikin Jl. Pasteur No. 38

Telp./Fax. 2034426-203595 Bandung 40161
}

di celana, encopresis yaitu apabila buang air besar di celana tanpa bisa disadari. ${ }^{1}$

Konstipasi disebabkan oleh berbagai macam keadaan; seperti kelainan di saluran cerna dan kelainan di luar saluran cerna. Salah satu penyebab diluar saluran cerna adalah keadaan hipotoni otot yang sifatnya umum. Konstipasi karena kelainan hipotoni disebut sebagai penyebab konstipasi pada anak yang mengalami sindrom Down., ${ }^{2,3}$

Sindrom Down adalah suatu anomali atau kelainan kromosom (kelebihan kromosom pada kromosom 21) yang didapatkan pada 1,3 per seribu kelahiran; anomali ini belum banyak diketahui penyebabnya. Diduga 
adanya kesalahan dalam perkembangan sel yang berakibat pada adanya 47 kromosom. ${ }^{4}$ Terdapat 3 tipe utama kelainan kromosom pada sindrom Down, tipe trisomi 21 bebas $95 \%$, tipe translokasi 3-4\% dan tipe mosaikisme $1 \% .^{3}$

Delapan puluh persen bayi sindrom Down lahir dari ibu berumur kurang dari 35 tahun sedangkan 1 dari 400 lahir dari ibu yang umurnya di atas 35 tahun. Sindrom Down merupakan individu yang mempunyai kelainan yang berbeda dengan orang normal terutama dalam hal kepribadian, cara belajar, kecerdasan, keluh kesah, rasa humor, sikap dan kelainan bawaan. Selain itu juga mempunyai kelainan pada organ yang memberikan gejala klinis yang berbeda. Salah satunya adalah kelainan di saluran cerna yang sering sekali menimbulkan masalah pada anak sindrom Down yang penyebabnya belum banyak diketahui. Terdapat literatur yang mengatakan kelainan gastrointestinal yang dihubungkan dengan sindrom Down dibagi dalam tiga grup yaitu ${ }^{5,6} 1$ ). Masalah struktural dan embrional, berupa anorektal (imperforata atau stenosis), duodenal atau jejunal atresia/stenosis, penyakit Hirschprung. 2). Masalah koordinasi dan motilitas; sulit makan, konstipasi, toddler diarrhea, gastro oesophagal reflux, batu empedu; 3). Otoimun, penyakit Celiak, hepatitis,

Konstipasi pada anak sindrom Down disebabkan karena gangguan motilitas yang kronik akibat hipotoni yang menyeluruh termasuk di sistem pencernaan. Belum banyak penelitian yang menyebutkan berapa besar konstipasi terjadi pada anak dengan sindrom Down. Konstipasi pada anak sindrom Down akan menambah masalah sehari-hari pada anak ini. Oleh karena itu pada penelitian ini ingin mengetahui berapa besar konstipasi memberikan masalah pada anak sindrom Down agar penanganan dan perawatan mereka lebih komprehensif5.

\section{Bahan dan cara}

Penelitian dilakukan secara cross sectional. Pasien yang ikut dalam penelitian ini adalah pasien dengan kelainan bawaan yang mempunyai fenotip sindrom trisomi 21 (sindrom Down) berusia 3-10 tahun yang datang ke RS Hasan Sadikin. Diagnosis ditegakkan berdasarkan pemeriksaan genetik yang telah dilakukan oleh peneliti sebelumnya, ${ }^{7}$ sehingga diketahui tipe kromosom termasuk aberasi penuh atau mosaik. Suatu formulir terstruktur telah dikembangkan untuk mengetahui data tentang konstipasi pada pasien. Formulir terdiri dari 20 pertanyaan mengenai konstipasi dan faktor risiko konstipasi sejak lahir sampai dilakukannya penelitian. Formulir dibuat sedemikian sehingga bisa dimengerti oleh orang tua pasien. Formulir disebarkan kepada pasien dan diisi oleh mereka, kemudian dikembalikan kepada peneliti. Dari 100 formulir yang disebar, separuhnya kembali dan bisa dianalisis.

\section{Analisis Data}

Analis data dilakukan dengan memakai program komputer SPSS versi 11. Untuk data mean memakai analisis student- $t$ test, untuk analisis korelasi memakai korelasi pearson, sedangkan untuk perbedaan dua variabel dengan data proporsi memakai Fisher exact test.

\section{Hasil}

Terdapat 50 formulir yang kembali kepada peneliti yang bisa dianalisis. Distribusi pasien tersebar dari usia 3-10 tahun. Jumlah pasien dengan tipe aberasi penuh terdapat pada 34 pasien sedangkan 16 pasien tipe mosaik. Jenis kelamin, berat badan, dan tinggi badan dari kedua kelompok tidak didapatkan perbedaan yang berbeda.

Pasien sindrom Down yang mengalami konstipasi sebanyak 32\% (16/50) Kejadian konstipasi pada pasien dengan aberasi penuh lebih banyak (35\%) dibanding pasien dengan mosaik (25\%). Akan tetapi secara statistik tidak didapatkan perbedaan bermakna diantara keduanya (Gambar 1).

Kejadian encopresis pada sindrom Down terdapat $26 \%$, sedangkan soiling lebih banyak ditemukan yaitu 30\%. Encopresis lebih banyak (p: 0,05) ditemukan pada sindrom tipe mosaik (58.3\%) dibandingkan dengan sindrom tipe aberasi penuh (27\%) (Gambar 2). Demikian juga soiling ditemukan lebih banyak pada sindrom tipe mosaik (38\%) dibandingkan pada tipe aberasi penuh (25\%), meskipun demikian secara statistik tidak berbeda bermakna (Gambar 3).

Hubungan kejadian konstipasi dengan beberapa faktor risiko tertera pada Tabel 1. Kejadian konstipasi pada anak dengan sindrom Down berhubungan dengan adanya rasa nyeri di perut ( $r: 0,5 ; \mathrm{p}: 0,002)$ 
dan rasa nyeri saat buang air besar ( r:0,56; p:0,002). Kejadian konstipasi pada anak sindrom Down tidak dipengaruhi oleh pola mekoneum saat baru lahir, jumlah minuman yang dikonsumsi dan jenis makanan yang di konsumsi. Demikian juga dengan adanya riwayat konstipasi pada keluarga.

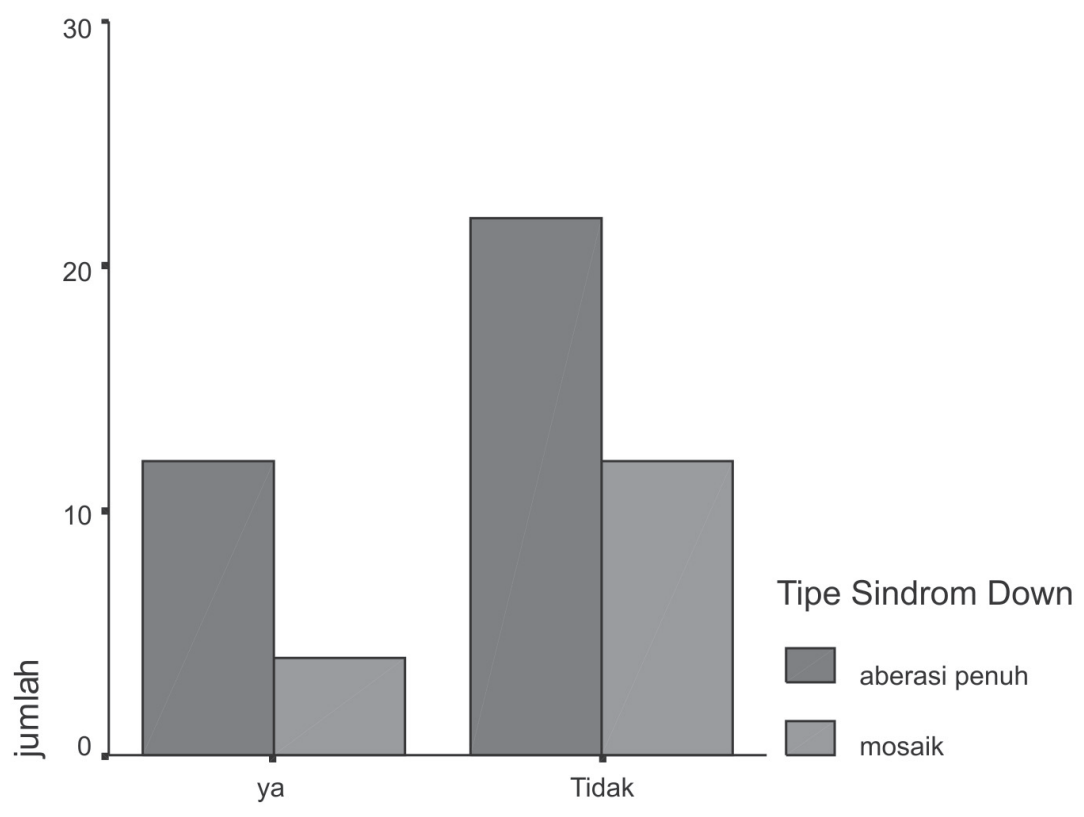

\section{Konstipasi}

Gambar 1. Kejadian konstipasi pada anak sindrom Down

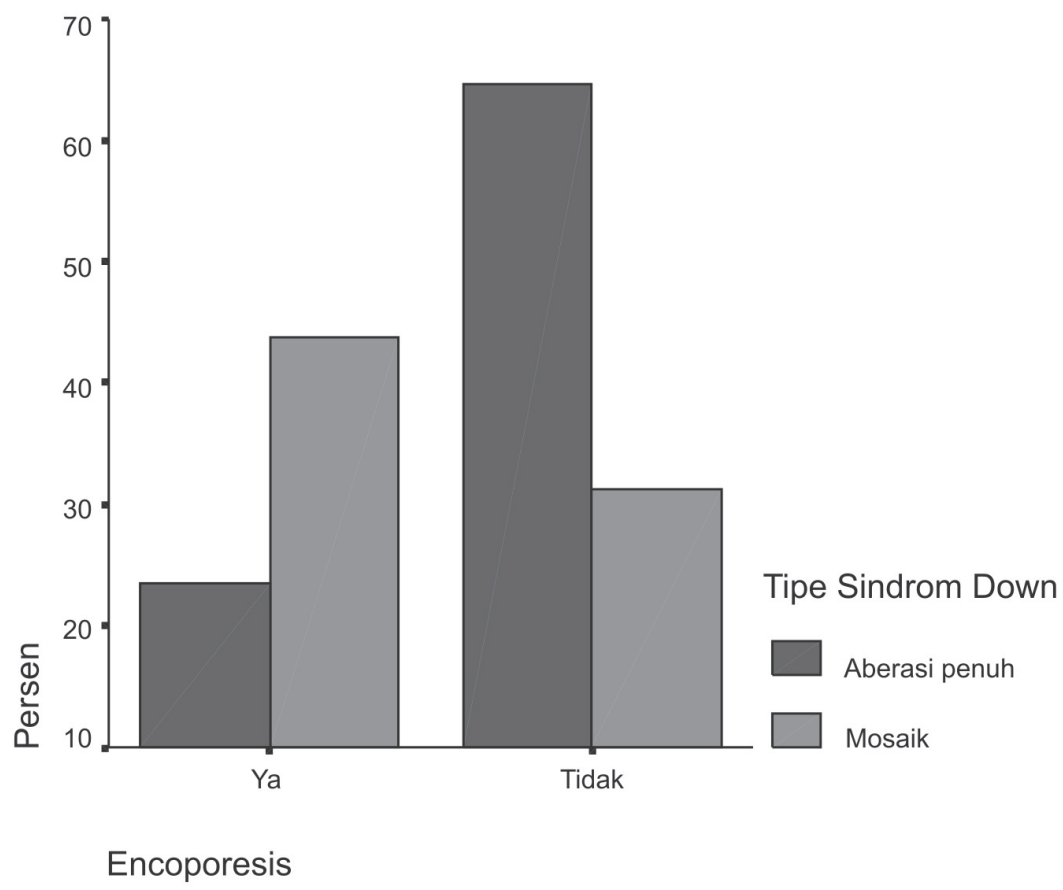

Gambar 2. Proporsi encopresis pada Sindrom Down 
Sari Pediatri, Vol. 6, No. 1, Juni 2004

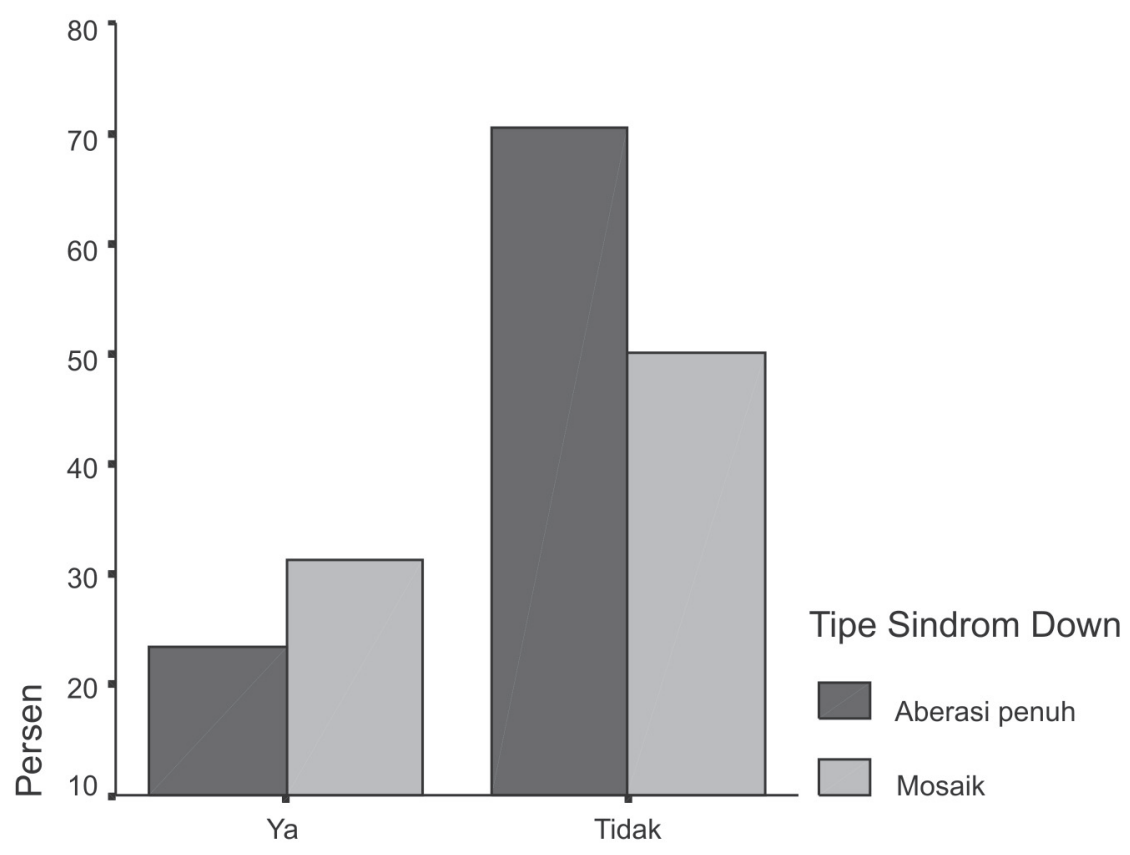

Soiling

Gambar 3. Proporsi soiling pada Sindrom Down

Terdapat hubungan yang bermakna antara kejadian encopresis dengan kejadian soiling (r: 0,44; $\mathrm{p}: 0,005)$ serta aktifitas anak yang berlebihan ( $\mathrm{r}: 0,49$; p: 0,001). Demikian juga kejadian soiling berhubungan dengan adanya gangguan pada saat buang air kecil (r: $0,38 ; \mathrm{p}: 0,02)$, dan pemakaian obat obatan (r: 0,32; p: 0,04). (Tabel 1)

\section{Pembahasan}

Maksud penelitian ini adalah untuk mengetahui berapa banyak anak sindrom Down akan mengalami konstipasi. Dari data yang didapat diketahui bahwa anak sindrom Down hampir setengahnya (32\%) mengalami konstipasi.

Konstipasi pada anak normal atau populasi normal bervariasi dari negara ke negara. Di Amerika berkisar 3-15\%, sedangkan di Eropa berkisar 3\% pada anak dan sampai $20 \%$ pada orang dewasa. Pada negara yang sedang berkembang prevalensi konstipasi ini lebih kecil dan berkisar $2 \%$ dari populasi. ${ }^{1}$ Perbedaan prevalensi ini mungkin disebabkan karena penyebab konstipasi sendiri sangat beragam sehingga pengaruh keadaan

Tabel 1. Hubungan kejadian konstipasi dengan beberapa faktor risiko

\begin{tabular}{lllllll}
\hline Kejadian & Nyeri perut & $\begin{array}{l}\text { Nyeri saat } \\
\text { b.a.b* }\end{array}$ & Soiling & $\begin{array}{l}\text { Aktivitas } \\
\text { berlebihan }\end{array}$ & $\begin{array}{l}\text { Gangguan } \\
\text { saat b.a.k** }\end{array}$ & Obat- obatan \\
\hline Konstipasi & $\mathrm{r}: 0,5$ & $\mathrm{r}: 0,56$ & & & & \\
& $\mathrm{p}: 0,002$ & $\mathrm{p}: 0,002$ & & & & \\
Enkopresis & & & $\mathrm{r}: 0,44$ & $\mathrm{r}: 0,49$ & & \\
Soiling & & & $\mathrm{p}: 0,005$ & $\mathrm{p}: 0,001$ & & \\
& & & & & $\mathrm{r}: 0,38$ & $\mathrm{p}: 0,32$ \\
\hline
\end{tabular}

* b.a.b: buang air besar

* b.a.b: buang air besar 
negara serta kebiasaan penduduknya akan memberikan perbedaan yang mencolok dalam kejadian konstipasi. Konstipasi pada anak sindrom Down belum banyak dilaporkan. Penelitian hanya menyebutkan bahwa pada anak sindrom Down akan terjadi konstipasi karena gangguan hipotoni. Angka yang pasti belum ada.

Penelitian ini menjawab pertanyaan seberapa besar anak sindrom Down akan mengalami konstipasi. Melihat angka 32\% anak sindrom Down mengalami konstipasi, ini menunjukan bahwa masalah konstipasi tersebut menjadi masalah yang serius. Diperkirakan gangguan hipotoni yang menyerang sistem muskuloskeletal akan menyerang juga otot saluran cerna pada hampir setengah pasien sindrom Down, sehingga berakibat kesulitan dalam buang air besar. Masalah ini akan menjadi lebih komplek karena selain hipotoni, ternyata saluran cerna anak sindrom Down juga mengalami gangguan pada mukosanya. Dengan adanya konstipasi maka kesempatan terjadi infeksi di saluran cerna menjadi lebih besar dibanding anak normal karena konstipasi akan menimbulkan motilitas usus terganggu yang akan berakibat pada gangguan ketahanan sistem pertahanan tubuh terutama di saluran cerna.

Meskipun secara statistik tidak berbeda bermakna, tapi angka absolut kejadian konstipasi lebih banyak diderita oleh pasien sindrom Down dengan aberasi penuh dibanding tipe mosaik. Ini menunjukkan bahwa gangguan motilitas karena hipotoni yang menyeluruh lebih banyak pada yang tipe lebih berat yaitu aberasi penuh dibanding mosaik. Hal ini dapat dijelaskan karena tentunya hipotoni akan berhubungan dengan derajat beratnya gangguan kromosomnya.

Encopresis dan soiling yang dalam definisi konstipasi termasuk gangguan pengeluaran tinja, atau bahkan dimasukkan dalam katagori konstipasi juga, ternyata kedua keadaan ini meningkat pada sindrom Down ( $30 \%$ dan 26\%). Pada anak normal gangguan ini hanya diderita oleh kurang dari $2 \%$ populasi. Angka ini tidak jauh berbeda dengan angka kejadian konstipasi. Hal ini menunjukkan bahwa hipotoni pada sindrom Down berakibat juga pada gangguan encopresis dan soiling. Kebalikan dari konstipasi, encopresis dan soiling lebih banyak di derita pada sindrom Down tipe mosaik dibanding aberasi penuh (Gambar 2,3). Hal ini menunjukkan bahwa tipe yang lebih ringan cenderung mempunyai gejala gangguan kesulitan buang air besar yang lebih ringan juga.

Kejadian konstipasi berhubungan dengan adanya rasa nyeri di perut dan rasa nyeri pada saat defekasi, hubungan ini cukup bermakna. Dapat dimengerti bahwa keadaan konstipasi akan menyebabkan tinja mengeras dan membesar sehingga kemungkinan menyebabkan nyeri saat tinja akan keluar. Demikian juga konstipasi akan menyebabkan perut kembung. Keadaan ini akan menimbulkan rasa sakit perut.

Adanya aktivitas yang berlebihan menimbulkan motilitas usus menjadi kurang baik pada sindrom Down, ini terlihat pada kenyataan yang ditemukan bahwa pasien yang aktif berhubungan dengan aktivitas yang berlebihan, meskipun hubungan ini sangat lemah.

Penelitian ini juga menunjukkan bahwa pada sindrom Down yang mengalami encopresis akan juga mengalami soiling, hal ini terlihat pada hubungan antara keduanya bermakna. Keadaan ini dapat dijelaskan bahwa gangguan dalam mengendalikan rasa ingin buang air besar selalu akan timbul pada anakanak yang mengalami gangguan motilitas, sedangkan encopresis dan soiling adalah dua keadaan yang disebabkan sulitnya pengendalian buang air besar.

Hipotoni yang terjadi pada sindrom Down terbukti memang menyeluruh. Pada penelitian ini menunjukkan bahwa gangguan pada pengendalian buang air besar berhubungan dengan gangguan buang air kecil, seperti ngompol dan kencing yang sering ditahan, sehingga pada beberapa penelitian ditemukan anak sindrom Down sering mengalami infeksi saluran kemih.

Pemakaian obat-obatan yang pada penelitian konstipasi pada anak normal sebagai salah satu penyebab, pada penelitian ini hanya berhubungan secara bermakna dengan kejadian soiling. Kemungkinan jenis obat obatan mempengaruhi kejadian ini. Pada penelitian ini tidak disebutkan macam obat yang dikonsumsi sehingga sulit menjelaskan pengaruhnya obat tersebut terhadap hipotoni.

Faktor risiko lain yang pada anak normal berperan terhadap kejadian konstipasi seperti konsumsi air dan makanan berserat serta riwayat keluarga, pada sindrom Down tidak terbukti mempunyai peran terhadap kejadian konstipasi, soiling maupun encopresis. Hal ini bisa dijelaskan bahwa konstipasi pada sindrom Down memang karena hipotoni bukan karena sebab lain yang banyak terdapat pada pasien konstipasi anak normal.

Kesimpulan dari penelitian ini adalah bahwa data menunjukkan pasien dengan sindrom Down hampir setengahnya mengalami konstipasi. Faktor risiko konstipasi pada sindrom Down tidak sama dengan 
faktor risiko konstipasi pada anak normal. Data ini sangat berguna untuk para klinisi dalam merawat dan menangani pasien sindrom Down.

\section{Daftar Pustaka}

1. Van der plas RN. Epidemiology and Patophysiology of constipation in clinical management and treatment options in children with defecation disorders. Academisch proferschrift. Amsterdam;1998. h.17-145.

2. Jones KL. Morphogenesis and dysmorphogenesis. Smith's recognizable pattern of human malformation, edisi ke-5 Philadelphia: WB Saunders; 1977. h.695-704.

3. Naussbaum RL, McInnes RR, Willard HE. Thompson $\&$ Thompson genetics in medicine, edisi ke-5 Philadelphia: WB Saunders;2001. h.135-55.
4. Thompson JS, Thompson MW. Genetics in medicine, edisi ke-3, Philadelphia: WB.Saunders Co; 1980: h.32030 .

5. Charlton.C. Gastrointestinal disorders in people with Down's Syndrome: an overview. A confrence of a royal Society of Medicine forum on learning disability and Down's Syndrome Medical Interest Group. Royal Society of Medicine, London; April 2001.

6. Levi J. The gastrointestinal tract in Down syndrome. Prog Clin Biol Res 1991;373:245-56.

7. Hidayat S. Pemeriksaan dermatoglifik dan penilaian fenotip tubuh anak sindrom Down sebagai uji diagnostik kariotip aberasi penuh trisomi 21. Desertasi program Pascasarjana Universitas Padjadjaran Bandung; 2002.

8. Gastrointestinal problem in children with Down's Syndrome http://www.downs-syndrome.org.uk/pd. 